Instructions for authors, subscriptions and further details:

http://brac.hipatiapress.com

\title{
De la Praxi de la Deriva a la Recerca del Remot
}

Marc Raventós Pagès ${ }^{1}$

1) Universitat de Barcelona. España

Date of publication: June 3rd, 2015

Edition period: June 2015 - October 2015

To cite this article: Raventós Pagès, M. (2015). De la praxi de la deriva a la recerca del remot. Barcelona, Research, Art, Creation, 3(2), 159-178. doi: 10.17583/brac.2015.1450

To link this article: http://dx.doi.org/10.17583/brac.2015.1450

\section{PLEASE SCROLL DOWN FOR ARTICLE}

The terms and conditions of use, except where otherwise noted, are related to the Open Journal System and to Creative Commons Attribution License (CCBY). The indication must be expressly stated when necessary. 
BRAC - Barcelona Research Art Creation. Vol. 3 No. 2, June 2015, pp. $159-178$

\section{From the Praxis of the Dérive to the Research of the Remote Space}

Marc Raventós Pagès

University of Barcelona

(Received: 25 February 2015; Accepted: 23 March 2015; Published: 3 June 2015)

\section{Abstract}

The dérive, as defined by Situationist theorist Guy Debord, is a procedure of action, more than of movement. It was a way to position oneself in space for the Surrealists, a kind of movement for the Situationists, a way to get carreid away space and in time and, ultimately, a mechanism used for artistic research. The remote space is a place that is simultaneously nearby and far-away, a mental place open to the knowledge. It is the domain of an imagined reality. After a long process of research and extensive field work, artist Marc Raventós explains how the praxis of the dérive serves as a tool for the research of the remote space. The act of dérive leads to a widening of subject matters and expressive languages. And, most importantly, this process becomes an extraordinary tool for artistic creation.

Keywords: dérive, travel, remote space, subjectivism, perceptionist, chromatic resonance, psycholandscape, psychogeography, darxan 
BRAC - Barcelona Research Art Creation. Vol. 3 No. 2, June 2015, pp. $159-178$

\section{De la Praxis de la Deriva a la Búsqueda del Remoto}

Marc Raventós Pagès

Universidad de Barcelona

(Recibido: 25 Febrero 2015; Aceptado: 23 Marzo 2015; Publicado: 3 Junio 2015)

\section{Resumen}

La deriva, tal y como la definió el teórico situacionista Guy Debord, es un procedimiento de acción, más que de movimiento. Es un posicionamiento espacial de los surrealistas, un procedimiento de los situacionistas, un dejarse ir en el espacio y en el tiempo y, en última instancia, un mecanismo para la investigación artística. Lo remoto es un lugar cercano y a la vez lejano, un lugar mental abierto al conocimiento, el dominio de la realidad imaginada. Después de un largo proceso de investigación y un extenso trabajo de campo, el artista Marc Raventós explica cómo la práctica de la deriva se convierte en una escuela de la mirada, en un mecanismo de mirada para el artista, en una herramienta para la investigación de lo remoto. El hecho de la deriva provoca una ampliación de temáticas y lenguajes expresivos. Y, lo más importante, este proceso se convierte en una herramienta extraordinaria para la creación artística.

Palabras clave: deriva, viaje, remoto, mirada, subjetivismo, percepcionista, resonancia cromática, psicopaisaje, psicogeografía, darxan 
BRAC - Barcelona Research Art Creation. Vol. 3 No. 2, June 2015, pp. 159-178

\section{De la Praxi de la Deriva a la Recerca del Remot}

Marc Raventos

Universitat de Barcelona

(Rebut: 25 Febrer 2015; Acceptat: 723 Març 2015; Publicat: 3 Juny 2015)

\section{Resum}

La deriva, tal i com la va definir el teòric situacionista Guy Debord, és un procediment d'acció, més que de moviment. És un posicionament espacial dels surrealistes, un procediment dels situacionistes, un deixar-se anar en l'espai i en el temps i, en última instància, un mecanisme per a la investigació artística. El remot és un lloc proper i alhora llunyà, un lloc mental obert al coneixement, el domini de la realitat imaginada. Després d'un llarg procés d'investigació i un extens treball de camp, explico com la pràctica de la deriva es converteix en una escola de la mirada, en un mecanisme de mirada per a l'artista, en una eina per a la recerca del remot. El fet de la deriva provoca una ampliació de temàtiques i llenguatges expressius. I, el més important, aquest procés es converteix en una eina extraordinària per a la creació artística.

Paraules clau: deriva, viatge, remot, mirada, subjectivisme, percepcionista, ressonància cromàtica, psicopaisatge, psicogeografia, darxan 
H e dedicat la meva tesi doctoral, titulada Ressonàncies cromàtiques del delta del Ganges, a la recerca d'un espai remot. El punt de partida d'aquest procés de recerca va ser una frase del novel-lista nord-americà John Steinbeck trobada en llegir els seus diaris: "Les contaré esta historia recreada en el condado que crecí, a lo largo del río que conozco tan bien, pero al que no añoro porque he descubierto que hay más" (Steinbeck, 2008).

Em van interessar dues idees: d'una banda, l'associació entre el paisatge viscut i l'acte de la creació; d'altra banda, el fet que és possible establir un vincle semblant amb un nou espai. La meva obra prèvia s'havia nodrit durant molts anys de les sensacions vinculades al delta de l'Ebre de la meva infància.

La frase de Steinbeck em va suggerir si en altres paisatges hi trobaria també el mateix tipus de ressonàncies que poguessin nodrir l'obra artística. Jo tenia un record del delta de l'Ebre com un espai d'horitzons infinits, nits sense contaminació lumínica, la connexió entre l'home i el paisatge, la sensació de llibertat de deixar la ment vagant per l'horitzó i la dilatació del temps.

Em vaig plantejar si podria ser el delta del Ganges (amb els paisatges d'horitzons infinits, llums i miratges) aquell altre riu que diu Steinbeck, que em nodrís per una nova obra.

A partir d'aquí, em vaig plantejar la següent hipòtesi: És el delta del Ganges el remot, l'altre riu del qual parla Steinbeck, on hi trobaré les ressonàncies del delta de l'Ebre de la meva infància?

L'objectiu de la tesi doctoral era demostrar l'existència de l'altre riu metafòric del qual parlava Steinbeck, mitjançant l'aplicació del meu mètode de deriva per a explorar el paisatge remot $\mathrm{i}$ analitzar les ressonàncies que aquest provoca en la meva obra artística.

En el marc d'aquest treball, cal entendre el concepte de remot com una projecció de la mirada de l'artista. Fa referència a un espai remot on el temps està suspès, $i$ on l'artista hi projecta un desig.

Des del punt de vista etimològic, el terme remot prové del llatí remotus, que deriva de removere. El prefix re expressa fonamentalment repetició, inversió del significat del verb primitiu o intensificació de l'acció.

Així, removere podria significar tant un retorn com un remoure o tornar sobre el mateix: vol dir, sobretot, moure o traslladar, de tal manera que remot suposa idea de desplaçament (un viatge de la realitat empírica a la realitat imaginada). 
El 1loc remot és una extensió de l'espai real, sense les contingències que imposa la realitat i sense els hàbits freqüents en aquesta realitat.

El remot és una experiència conceptual. L'antropòleg social britànic Edwin Ardener fa referència a la relativitat del concepte de remot.

I have pointed out that, for Europe, remote areas of the globe have had a different conceptual geography, and have been perceived to exist on a different time-scale from the central areas (Ardener 1975, 1985). But we are not now opening up a familiar centre/periphery discussion - if only for the reason that most such discussion depends on an acceptance of known centres with known peripheries. On the contrary, the age of discovery showed us that the remote was actually compounded of imaginary as well as real places; yet they were all of equal conceptual reality or unreality before the differences were revealed. Brazil, California, India, Africa, Libya, Ethiopia - all were to one extent or other imagined (names ransacked from various sources), yet all were located eventually in limited and specific places (Ardener, 1975, p. 213).

Per la seva banda, Careri recalca el caràcter empàtic de l'espai remot:

El espacio aparece como un sujeto activo y vibrante, un productor autónomo de afectos y de relaciones. Es un organismo vivo con carácter propio, un interlocutor que sufre cambios de humor y que puede frecuentarse con el fin de establecer un intercambio recíproco. [...] Este territorio empático penetra en la mente hasta sus estratos más profundos, evoca imágenes de otros mundos donde la realidad y la pesadilla conviven juntos, transporta al ser a un estado de inconsciencia en el cual Yo todavía no queda determinado (Careri, 2003, p. 80).

El remot és el lloc on es compleix el que s'espera del viatge. És un espai que projecta el propi viatger. El viatger aconsegueix allunyar-se de la quotidianitat i assolir aquest nou espai, que és una projecció del seu propi desig.

L'escriptor Claudio Magris té algunes reflexions molt pertinents que serveixen per il-lustrar el concepte del remot. Per a Magris, el remot ofereix una dualitat espacial que resultarà molt interessant en el context d'aquesta investigació: "Viatjar sentint-se sempre, simultàniament, en un món ignot o a casa" (Magris, 2008, p. 12). L'espai remot és, doncs, un lloc conegut alhora que desconegut. 
Magris vincula l'espai remot amb la sensació d'aturar el temps que s'ha apuntat anteriorment:

El viatge-escriptura és una arqueologia del paisatge; el viatger -l'escriptor- baixa com un arqueòleg als diversos estrats de la realitat, per llegir fins i tot els indicis amagats sota altres indicis, per recollir totes les vides i les històries que pugui i salvar-les del riu del temps, de la onada anul·ladora de l'oblit"' (Magris, 2008 p. 20).

L'artista i pedagog Jean-François Pirson parla de l'espai que es construeix el caminant en el seu viatge. El remot és un espai fluid, mutable, que respon a les necessitats pròpies del viatger, que n'inventa una cartografia: "Le marcheur invente la cartographie de la ville fluidifiée, il construit et produit son territoire loin du plan de la ville portraiturée (le calque)" (Pirson, 2008 p. 90).

L'urbanista i antropòleg italià Franco La Cecla explora el concepte de perdre's per un espai: "Los lugares se convierten en una especie de máquina a través de la cual se adquieren nuevos estados de conciencia" (Careri 2003 p. 46). L'espai remot permet assolir un nou estat de consciència que connecta amb el passat de la infància.

El remot és un espai mental, un lloc proper i alhora llunyà, un lloc mental obert al coneixement, el domini de la realitat imaginada. És un lloc mental i imaginari, suspès en el temps, on es desenvolupa el llenguatge, on neix la creació. El remot té una gran relació amb el temps: és un espai de temps condensat, on hi conviuen passat i present.

El remot permet conservar en l'actualitat totes aquelles característiques del passat que semblaven oblidades, aturar el temps i salvar el passat de l'oblit. Aturant el temps, l'artista aconsegueix conservar els paisatges d'infància i, d'alguna manera, conservar-se ell mateix. L'espai remot permet assolir un nou estat de consciència que connecta amb el passat de la infància. El recorregut passa a ser el jo que va comunicant-se amb els jo anteriors, creant sempre un nou jo, i així cíclicament.

S'estableix entre l'observador i el paisatge remot una relació íntima i secreta, una correspondència capaç de transcendir el propi paisatge. És, doncs, un espai purament subjectiu.

Tal i com hem vist, el remot es planteja com una projecció del desig de tornar a la infància. Aquest moviment vers la infància es tradueix en un desplaçament al naixement del llenguatge artístic. Un cop es compleix la projecció del desig i es troba el remot, ja no es projecta més aquest desig de 
tornar a la infància. El remot es manifesta en aquest cicle de comunicació amb els jo anteriors i creació de jo nous. En descobrir el remot, ja no s'enyora el passat perquè s'ha trobat una font contínua de creació.

La mirada del remot es converteix en una de les eines de l'art, del pensament artístic. Es comprova que el remot es pot trobar en qualsevol lloc on l'artista exerceixi una mira activa, ja que la projecció de la mirada és en sí un tipus de creació.

A l'igual que el riu de Steinbeck, "al que no añoro porque he descubierto que hay más", l'exploració del paisatge remot i el descobriment constant de realitats són possibles en qualsevol lloc.

Un cop definit el concepte de remot, cal descriure l'altre concepte fonamental per aquest estudi: la ressonància. Quan parlo de ressonància, em refereixo a la interpretació individual de la realitat mitjançant l'observació i la visió interior de l'artista. L'individu es converteix en una capsa de ressonàncies de l'entorn.

El metge i pintor alemany Carl Gustav Carus exposa el seu ideari estètic en les seves Cartas y anotaciones sobre la pintura de paisaje.

Carus utilitza els termes Erdlebenbild i Erdlebenbildkunst, que el traductor (José Luis Arántegui) tradueix com a 'geobiografía' i 'arte geobiográfico' respectivament.

Aquests concepte resulten molt interessants en el marc d'aquesta investigació, ja que es refereixen a les imatges de les experiències viscudes, les imatges que tenim de les nostres vivències. A més, vincula les imatges creades per l'artista amb l'espai de la creació, una vinculació molt pertinent.

En els seves cartes, Carus explica que per captar una imatge geobiogràfica, cal captar la vibració o la ressonància sentimental personal davant de la realitat física:

Cuando contemplamos la Naturaleza o una obra de arte, captamos los objetos como representaciones, poniéndolos en relación con nuestra conciencia, sólo que con ello también nuestro yo se relaciona con un nuevo ámbito del mundo externo (esto es, entra en un estado interno diferente); con lo cual, la sensación que se suscite tiene que ser armónica con una atmósfera concreta, con una determinada resonancia (Stimmung) que se manifieste en la vida de la Naturaleza a través de ese fenómeno, o bien se corresponda con el sentimiento del que proceden, como de una misma unidad interna, la representación y luego la configuración real de la obra (Carus, 1992, p. 81). 
En el seu llibre Voyage à l'île de Rügen, Carus descriu el seu viatge a aquesta illa del Mar Bàltic seguint el rastre de les pintures de Caspar David Friedrich. El seu viatge il·lustra una actitud romàntica per fer una síntesi entre l'ésser i l'univers, un moviment de l'exterior cap a l'interior.

Per a Carus, el viatge és un viatge en el temps mental, un viatge on l'individu pot observar el pas del temps en la seva totalitat, en el seu absolut. En el seu viatge podrà observar la creació geològica de la primera Alemanya i el naixement dels primers pobladors alemanys a través de runes arqueològiques, "abandonar-se a aquesta natura monòtona" (Carus, 1999, p. 61) i fer un viatge per un temps que s'atura, convertint-se en un espai mental.

Tant Carl Gustav Carus com el seu amic Caspar David Friedrich, que havia estat abans a l'illa per pintar els paisatges, comparteixen aquesta manera de visitar l'illa de Rügen i convertir-la en un espai mental, en un espai sublim. A partir de la seva visita, l'illa de Rügen mai serà igual pels alemanys, s'haurà convertit en una illa mental, metàfora evocativa del sentiment romàntic alemany.

Un cop entesos els conceptes de remot i ressonància, és hora de plantejar el mecanisme de recerca. Proposo com a eina per a la recerca la pràctica de la deriva. La deriva constituirà una eina extraordinària per a la creació artística.

Què és, però, la deriva? Totes les accepcions d'aquesta paraula apunten a un sentit de desviació, de variació, de desplaçament lateral, així com d'aleatorietat. Anar a la deriva significa anar sense govern. No obstant, en el marc d'aquest estudi, m'interessa primordialment l'ús de la paraula deriva que van fer els situacionistes.

En el seu estudi París i l'aglomeració parisenca, Chombart de Lauwe assenyala que "un barri urbà no està determinat únicament pels factors geogràfics i econòmics, sinó per la representació que en tenen els seus habitants i els habitants dels altres barris" (Lauwe,1952). La Internacional Situacionista es basa en aquest mapa relatiu i personal.

Els situacionistes proposen una disciplina anomenada psicogeografia, enfocada a percebre l'entorn geogràfic a partir dels actes i les emocions subjectives de l'observador. Es tracta d'una ciència subjectiva que té a veure amb el joc i la creativitat, i que proposa estratègies inventives per explorar ciutats.

Les tàctiques proposades per la psicogeografia es basen enormement en l'atzar. En aquest marc de relativisme, Guy Debord presenta la seva teoria de la deriva, un desplaçament a través de l'espai espontani, sense planificació. 
No obstant, no és un atzar qualsevol. Guy Debord recalca que l'aleatorietat de la deriva és molt diferent de la que pot experimentar un passejant qualsevol. I és que l'objectiu, ja de base, és un altre. L'artista que camina a la deriva ho fa amb un objectiu concret, lluny de la mera distracció del passeig. És un nou model de comportament:

Un ensayo primitivo de un nuevo modo de comportamiento se obtuvo con lo que llamamos la deriva, que es la práctica de una confusión pasional por el cambio rápido de ambientes, al mismo tiempo que un medio de estudio de la psicogeografía y de la psicología situacionista. Pero la aplicación de esta voluntad de creación lúdica se ha de extender a todas las formas conocidas de relaciones humanas, e influenciar, por ejemplo, la evolución histórica de sentimientos como la amistad y el amor. Todo lleva a creer que alrededor de la hipótesis de la construcción de situaciones se halla lo esencial de nuestra investigación (Debord, 1957).

Resulta interessant la idea de la "confusió passional pel canvi ràpid d'ambients", que recupero més endavant.

Per definició, la psicogeografia combina coneixements i estudis subjectius i objectius. La teoria de Debord serveix com a manual d'instruccions per al procediment psicogeogràfic, executat a través de l'acte de la deriva.

En la línia de Debord, jo proposo un Manifest de la deriva (vegeu apartat 5). Es tracta d'una proposta pràctica per a artistes, confeccionada a partir del meu treball de camp. El manifest proposa la deriva com a mecanisme de creació per a la recerca de l'espai remot, i suggereix una sèrie de procediments de registre de realitat.

Tal i com veurem en el manifest, i sempre en la línia de Debord, en una deriva l'artista abandona la motivació o intenció habitual del moviment (el desplaçament) i es deixa endur per estímuls visuals, sonors, olfactius, etc. Aquest "deixar-se anar" és un requisit necessari de la deriva. El recorregut quedarà, doncs, dominat per l'atzar i per variables espontànies imprevisibles.

En aquesta deriva, l'artista reinterpretarà l'espai, s'apropiarà d'ell. El situacionista Ivan Chtcheglov, creador original del concepte de deriva, proposa en el seu Formulari per a un nou Urbanisme una reinvenció de la ciutat a través d'aquests recorreguts atzarosos. Algunes d'aquestes idees de Chtcheglov serviran per al Manifest de la deriva: 
Nos proponemos inventar nuevos escenarios móviles. [...] La actividad principal de los habitantes será la DERIVA CONTINUA. El cambio de paisajes entre una hora y la siguiente será responsable de la desorientación completa [...] (Chtcheglov, 1999).

La deriva és un mètode de treball per a l'artista, una manera de deixar-se sorprendre per la realitat que va emergent. La deriva es nodreix de l'atzar per trobar una direcció. Aquest moviment ens remet a una actitud lúdica d'infància.

Aquest deambular consisteix en caminar per assolir un estat mental determinat, una desorientadora pèrdua de control. És un mitjà a través del qual s'entra en contacte amb la part inconscient del paisatge.

Gràcies a la tècnica de la deriva, es pot experimentar la duplicitat de temps i espais: "qualsevol punt pot estar connectat amb qualsevol altre" (Deleuze i Guattarri, 1980, p.13).

Cal recalcar la importància de la idea de dualitat espacial, que resulta fonamental en el context d'aquest article. En emprendre el viatge cap a un lloc desconegut, el viatger té l'objectiu d'arribar a un lloc que li és propi.

Arrel del treball de camp realitzat, s'ha comprovat que el deixar-se perdre pel paisatge fa que un se l'apropiï, se'l faci seu. Del procés de derivar se'n pot extreure la possibilitat de crear un món propi, una geografia mental/ sentimental pròpia de l'artista.

La deriva serveix com a recerca del llenguatge artístic. S'observa que el fet de perdre's provoca que les coses apareguin. L'artista es queda sorprès per la direcció en la qual el porten les seves passes, que li revelen imatges interiors que abans ell mateix ignorava. Així, si no es troba el que es busca, s'enriqueix l'experiència amb altres coses no esperades.

A partir del fenomen de la deriva, s'acumulen les imatges, s'amplia la mirada $i$ augmenten les possibilitats de ressonància creativa. Es crea un vincle entre paisatge, deriva $i$ imatge. Aquest vincle es reprodueix en ressonància en la creació de l'obra d'art i també en l'observació d'aquesta obra. És a dir, en la creació de l'obra, el suport pictòric esdevé un paisatge que es recorre amb els pinzells seguint el mecanisme de la deriva i on s'hi projecta la mirada. El resultat del procés serà la creació d'una imatge artística.

En el marc del meu treball de doctorat, anomenada Ressonàncies cromàtiques del delta del Ganges, vaig realitzar un extens treball de camp, basat en l'exploració de les ressonàncies cromàtiques durant la deriva i la posterior creació artística. El treball de camp es va estructurar en dos viatges 
(2009-2010; 2011-2012).

L'objectiu del primer viatge és buscar el paisatge remot de la infància, trobar aquell delta de l'Ebre de la infància en el delta del Ganges i traçar un paisatge de la memòria. S'observarà l'estat mental del pintor en el moment que es pinta, que es plasma també en la pintura, aquell moment on el temps s'atura.

Es planteja un joc atemporal on el temps de la infància en el delta de l'Ebre existeix en el delta del Ganges actual, considerat con un present etern. La ruta consisteix en volar des de Barcelona fins a Calcuta, i d'allà viatjar a Bangladesh.

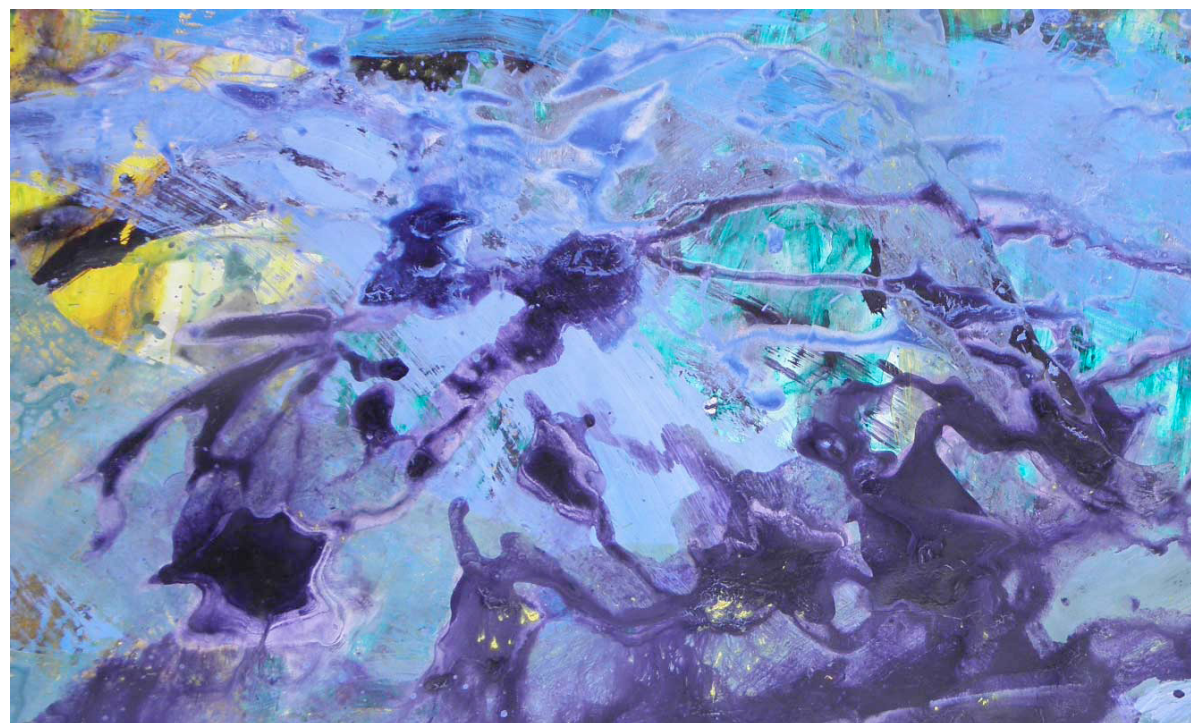

Figura 1. Aigües del Ganges. Pintura acrílica sobre tela de 1li. Gran format 10 x 1,5 m.

La idea inicial és recórrer a la deriva el delta del Ganges, equipat únicament amb un mapa com a referència per poder referir-se a algun nom en pujar als autobusos o altres mitjans de transport. Es confia que allà on s'arribi es trobarà algun o altre lloc per dormir i alguna cosa per menjar al carrer. El recorregut anirà naixent del mateix atzar del moment $i$ de les persones que es vagin creuant. S'espera que aquest deixar-se portar permeti aturar el temps. En aquest temps suspès, es retrobarà aquell delta de l'Ebre de la infància. 


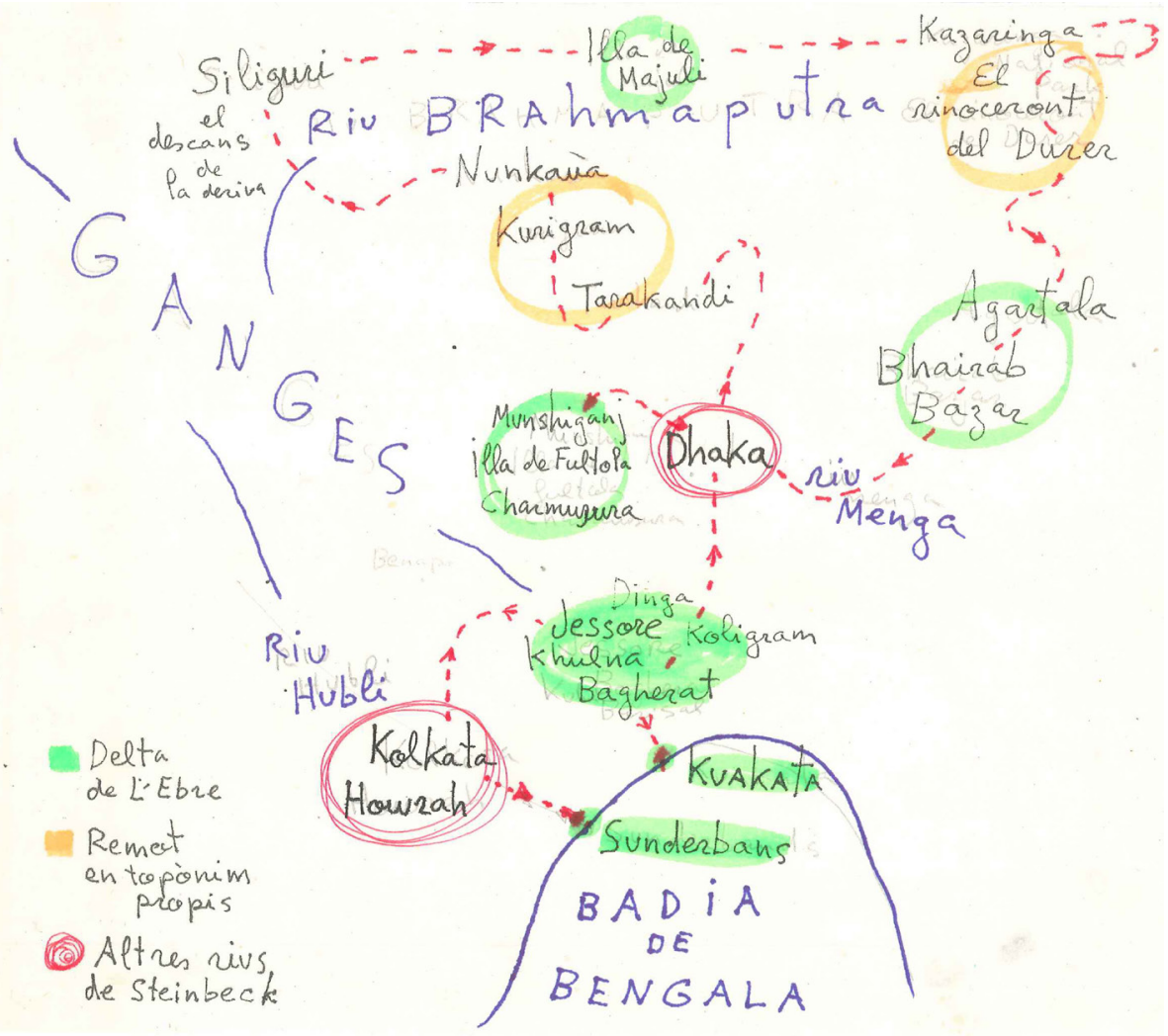

Figura 2. Mapa de les derives del primer treball de camp (2009-2010).

Es busca l'instant per fer un art que neixi de l'experiència. Les ressonàncies seran el resultat d'un procés de viatge que permeti a l'artista trobar una direcció per a la seva creació. Així, en la deriva, se segueix l'impuls amb l'objectiu d'avivar els sentiments, d'estimular la intuïció, la creació i la sublimació de sensacions.

Durant el treball de camp, es documenta la relació entre l'entorn i el subjecte a través del dietari escrit, els esbossos, la pintura, la fotografia i l'enregistrament de sons. 
El dietari recull el temps cronològic. Durant el treball de camp, s'escriu regularment un dietari dels fets viscuts, imatges percebudes i experiències de cada dia. En recórrer el paisatge se segueix una trajectòria lineal. Després en arribar la nit, el cervell recupera tota la col-lecció de percepcions de forma circular, com si fossin núvols que hi ha al voltant. El dietari es redacta en aquest moment, de manera que es capta la realitat a partir d'aquestes percepcions.

En la confecció de dibuixos in-situ en quaderns o en materials locals, es pinta l'empremta del dia, el temps condensat, capturant fragments de la realitat per construir una visió pròpia. És un treball de registre immediat i subjectiu. L'objectiu és documentar el procés de sublimació de sensacions a través de les imatges capturades, creant el un puzzle singular que té sentit poc a poc.
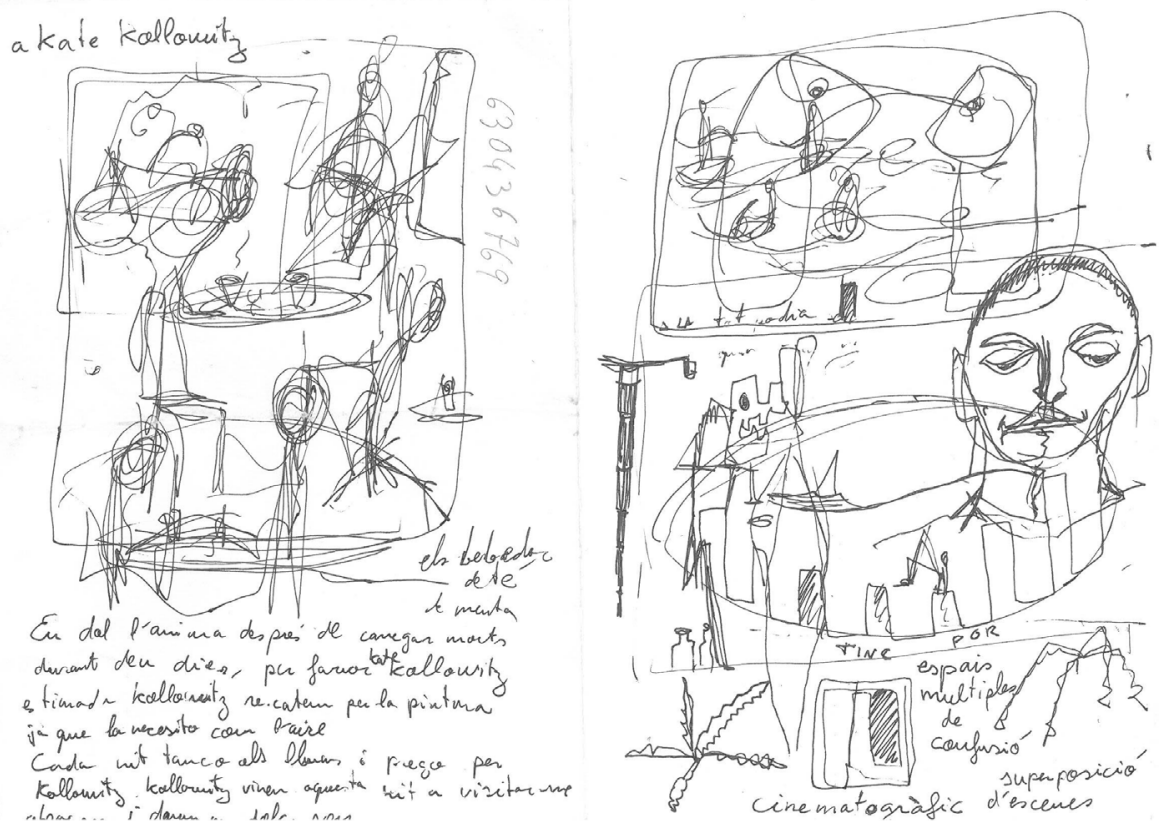

Figura 3. Dibuix de tinta sobre paper de llibreta Moleskine de les derives per Kolkata. $14 \times 18 \mathrm{~cm}$. 


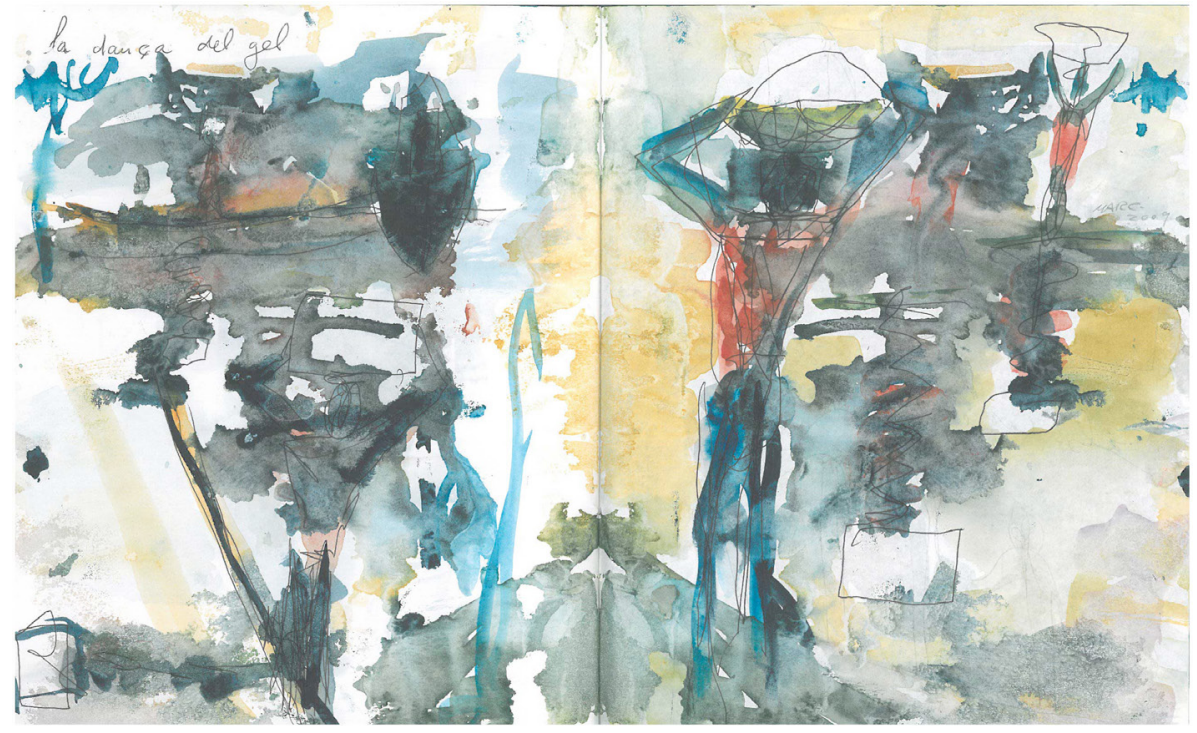

Figura 4. La dansa del gel. Aquarel·la i tinta sobre paper. 15 x $21 \mathrm{~cm}$.

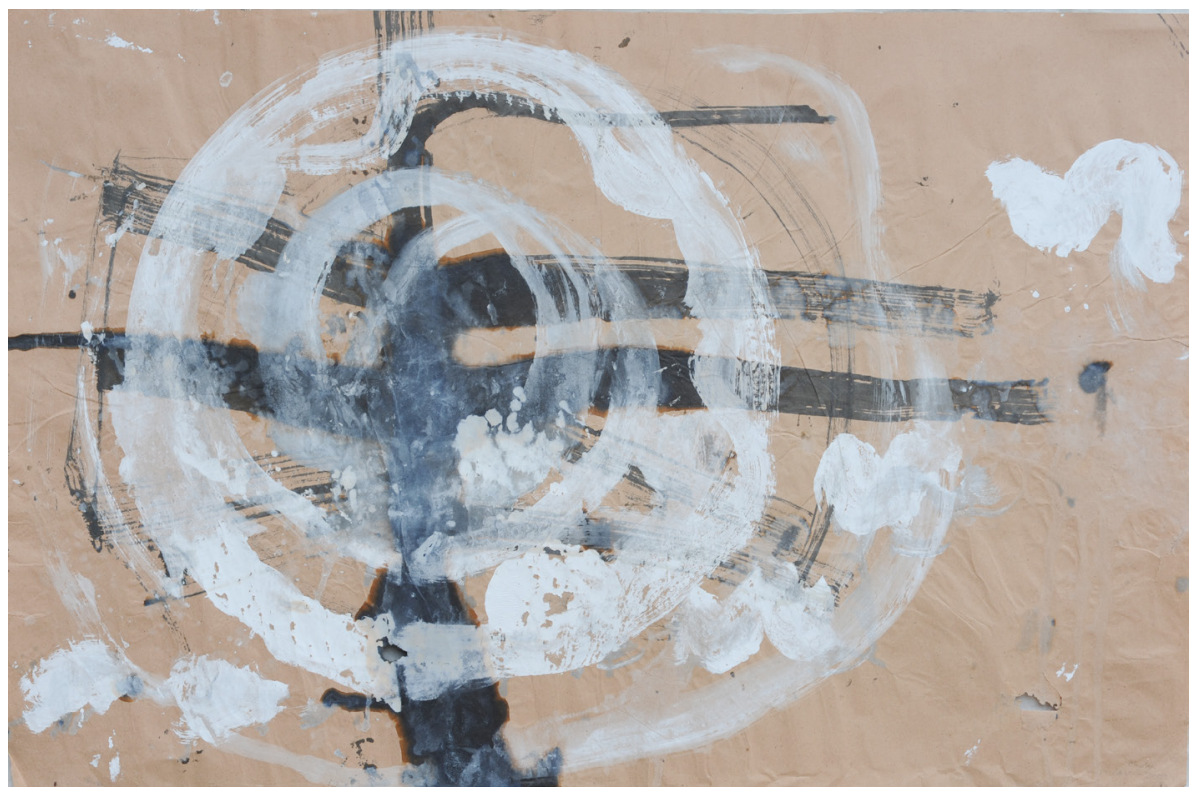

Figura 5. Soroll de Dhaka. Tinta i pintura acrílica sobre paper d'estrassa. 85 x $128 \mathrm{~cm}$. 


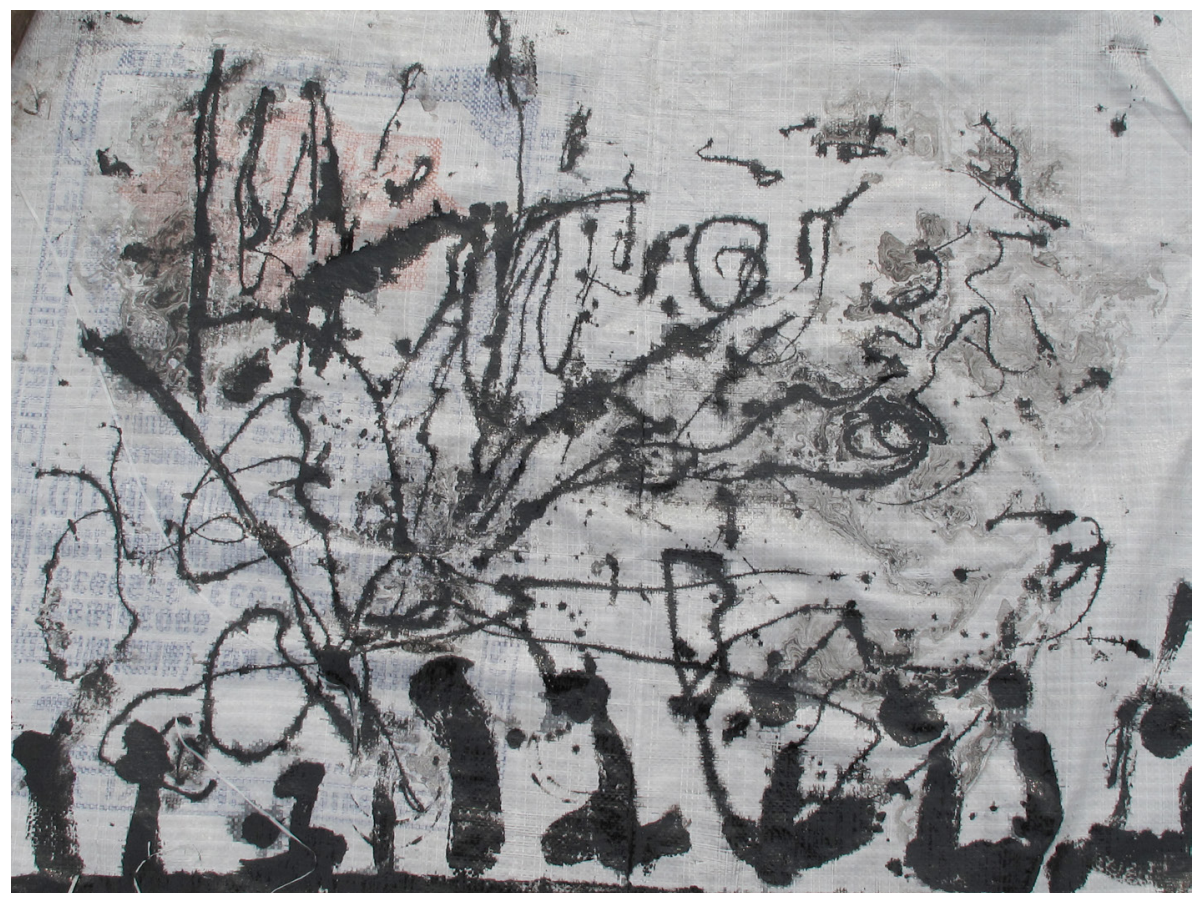

Figura 6. La nit a Kolkata. Esmalt negre sobre sac de plàstic. 94 x $115 \mathrm{~cm}$.

A l'hora de fotografiar, la tècnica seguida és la següent: passejar amb la càmera a la mà baixada, posant-la en marxa $\mathrm{i}$ anar fent fotos per on camini $\mathrm{i}$ cridin l'atenció els colors o d'altres coses. La mirada sempre va lliure, sense mirar per la lent, i és el gest de la mà el que capta tot allò que es veu o aquella sensació de moviment per on es passa. En observar les imatges, domina la visió pictòrica. Així, amb les primeres imatges es busquen textures per possibles pintures: reflexes a l'aigua que poden semblar pinzellades, humitats a les parets que podrien ser fons de quadres o pintures abstractes, etc. Es cerca un llenguatge pictòric per després expressar-se. 


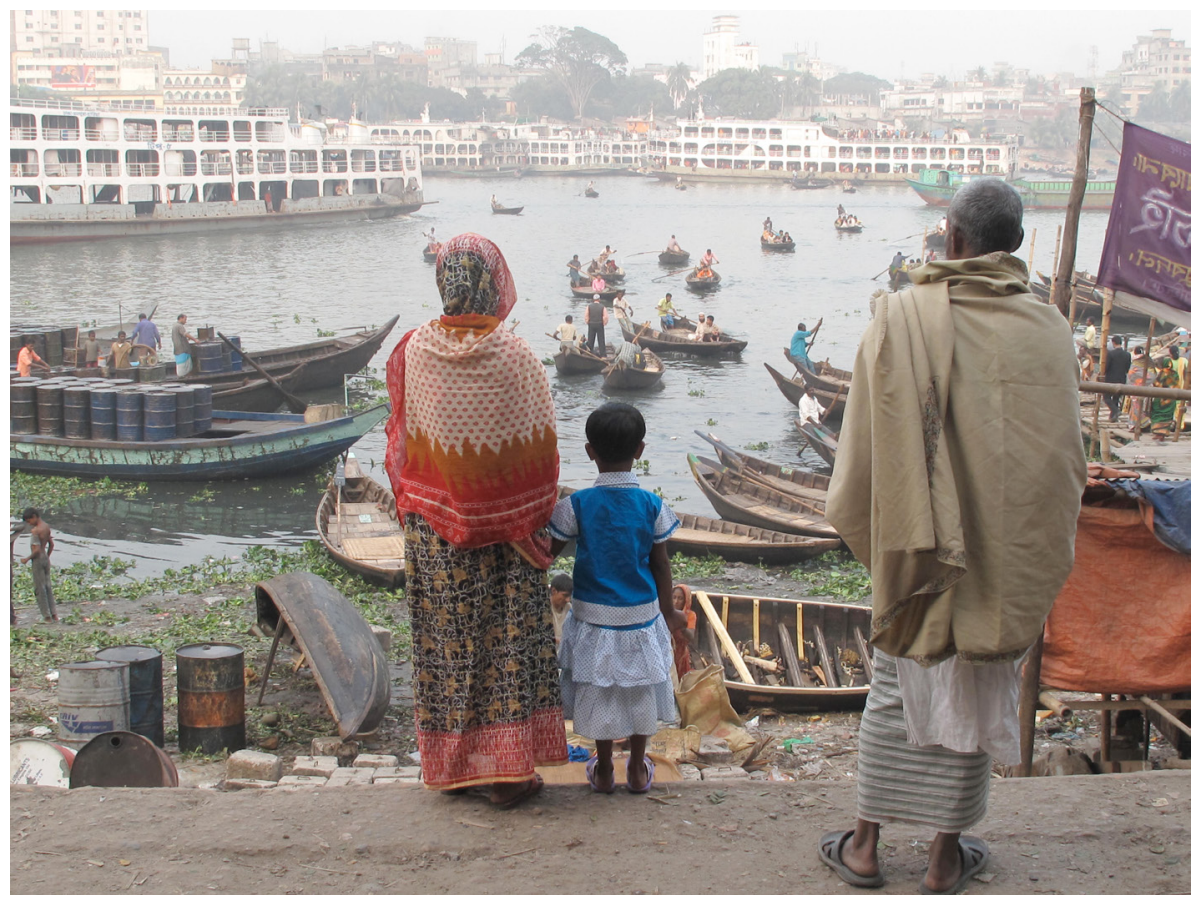

Figura 7. Evocant a Caspar David Friedrich. Port fluvial de Dhaka 2010.

Per últim, tenim la gravació de sons. L'interès que té el registre sonor és documentar el so del paisatge. Es concep la gravadora com una eina objectiva que aconsegueix enregistrar el so envoltant, allà on la percepció subjectiva de l'artista s'esgota per la força aclaparadora de l'entorn. Amb el registre sonor s'agafa consciència de la realitat de l'espai. A més, la percepció a través de la visió humana i l'ull de la càmera fotogràfica està limitada a una sola direcció. Per compensar això, s'opta per capturar la realitat amb una gravadora de so, la qual cosa permet la percepció perifèrica de 360 graus. Les ciutats tenen el seu propi univers sonor, que es pot capturar mitjançant la gravadora. 


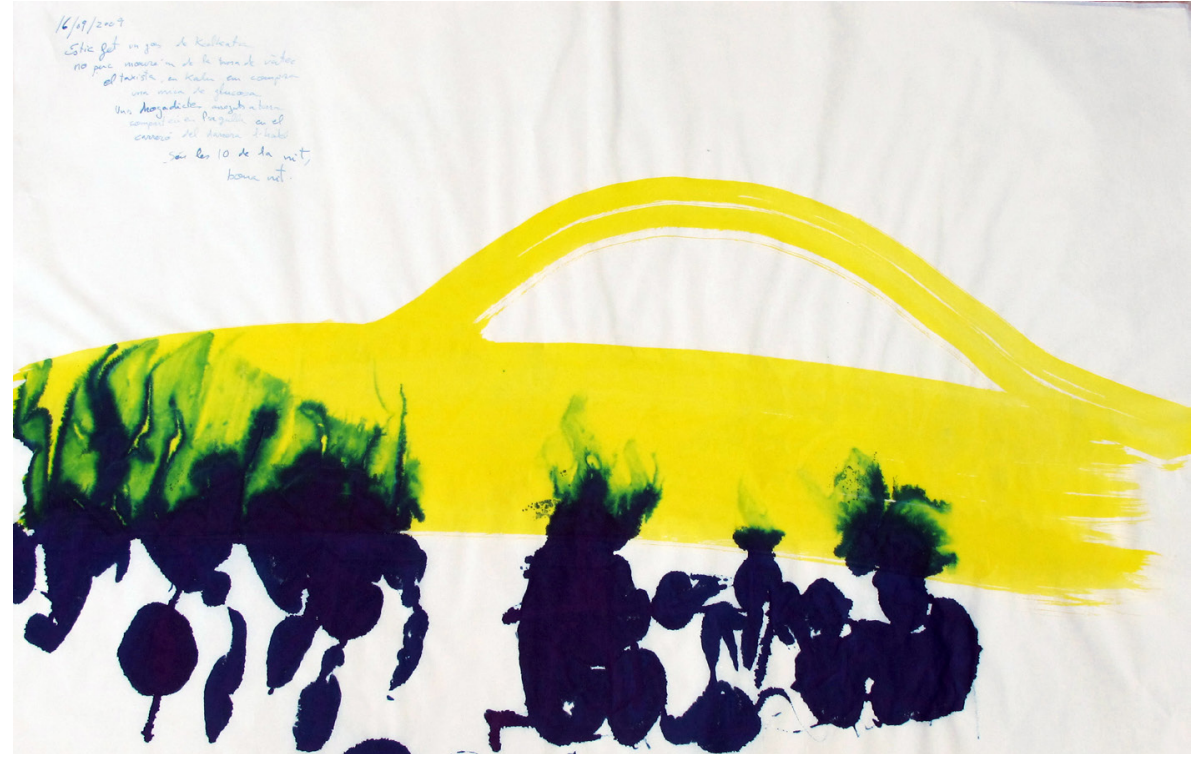

Figura 8. Taxi i drogadictes a Kolkata. Aquarel·la sobre paper d'arròs.

Al llarg de tot el treball de camp, es va consolidant la deriva com a mecanisme de recerca de ressonàncies per a la recerca artística. El corpus realitzat i l'experiència viscuda donen la seguretat d'haver trobat un mètode de recerca molt vàlid per a la creació. Tant el treball de camp com la recerca efectuada tenen un resultat molt clar, que és un mètode personal però absolutament transferible. Un mètode que permetrà passar de la praxi de la deriva a la recerca del remot.

A continuació es proposa el Manifest de la deriva. El manifest consta de dues parts, una de conceptual i una de pràctica. La primera és un decàleg que estableix les bases i idees centrals del procediment. La segona descriu el procediment pel qual es podrà aplicar la praxi de la deriva per a la recerca del remot. Aquest mecanisme es considera totalment extrapolable. Es convida a qualsevol artista a seguir aquestes instruccions per aplicar el procediment a la pròpia obra artística. 


\section{Manifest de la Deriva}

\section{Idees Fonamentals}

1. Experimentar la deriva com a escola de la mirada personal

2. Entendre l'artista com a caixa de ressonància

3. Inventar nous escenaris mòbils de deriva contínua

4. Deixar-se endur per estímuls visuals, sonors, olfactius

5. Perdre's en el paisatge i apropiar-se'n per crear un món propi

6. Crear una cartografia mental pròpia de l'artista, amb topònims poètics personals

7. Reinventar l'entorn a través de recorreguts atzarosos

8. Cercar l'estat mental del remot

9. Convertir les ressonàncies obtingudes en llenguatge artístic

10. Entendre l'individu com un creador de nous llenguatges

\section{Instruccions}

1. Selecciona una o més formes de registre de la mirada: escriptura, dibuix, pintura, fotografia, vídeo, so, etc.

2. Tria un punt de sortida i no pensis en cap punt d'arribada

3. No cerquis cap informació preconcebuda d'allà on vas

4. Agafa un transport a l'atzar: a peu, metro, tren, autobús, cotxe, bicicleta, avió, globus, etc.

5. Deixa't endur pels estímuls de tot tipus i que aquests marquin la teva deriva

6. Canvia de mitjà de transport si així t'ho demana un estímul

7. Deixa que l'atzar decideixi per tu noves direccions, pauses i visites

8. Centra't en una percepció espacial, evitant opcions racionals, lògiques o lineals

9. Tot paisatge mental que neixi a partir de la deriva és susceptible de ser registrat i/o cartografiat

10. Observa tot el material per tenir una visió global del que has creat 


\section{Referencias}

Ardener, Edwin (2006). Remote areas, The voice of prophecy and other essays. New York: $\mathrm{Hb}$.

Careri, Francesco (2003). Walkspaces. El andar como práctica estética. Barcelona: Gustavo Gili.

Carus, Carl Gustav (1992). Cartas y anotaciones sobre la pintura de paisaje. Madrid: La Balsa de la Medusa.

Carus, Carl Gustav (1999). Voyage à l'île de Rügen. Sur les traces de Caspar David Friedrich. Charenton: Premières Pierres.

Chtcheglov, Ivan (1999). Formulario para un nuevo urbanismo, a Internacional situacionista, vol. 1: La realización del arte. Madrid: Literatura Gris.

Debord, Guy (1957). Revolución y contra-revolución en la cultura moderna:

Fuera de Banda: Situacionistas: ni arte, ni política, ni urbanismo, 4.

Debord, Guy (1999). Teoría de la deriva: Internacional Situacionista.

Madrid: Literatura Gris.

Deleuze, Gilles i Guattari, Félix (1980). Rizhome: Mille plateaux. Paris: Minuit.

Lauwe, Chombart (1952). Paris et l'agglomération parisienne. Paris:

Bibliothèque de Sociologie Contemporaine, P.U.F.

Magris, Claudio (2008). El viatjar infinit. Barcelona: Edicions de 1984.

Marí, Antoni (2007). De Ítaca a Rothko a La Vanguardia, 21 de noviembre.

Pirson, Jean-François (2008). Entre le monde et soi. Bruxelles: La lettre volée.

Steinbeck, John (2008). Diario de una novela: las cartas de "Al este del Edén". Madrid: Bartleby Editores. 
178 Marc Raventós - Praxis de la deriva

Marc Raventós Pagès: Universidad de Barcelona.

Contact Address: Facultad de Bellas Artes. Universidad de Barcelona.

c/ Pau Gargallo 4, 08028 Barcelona (España).

E-mail address: faraon466@yahoo.com 